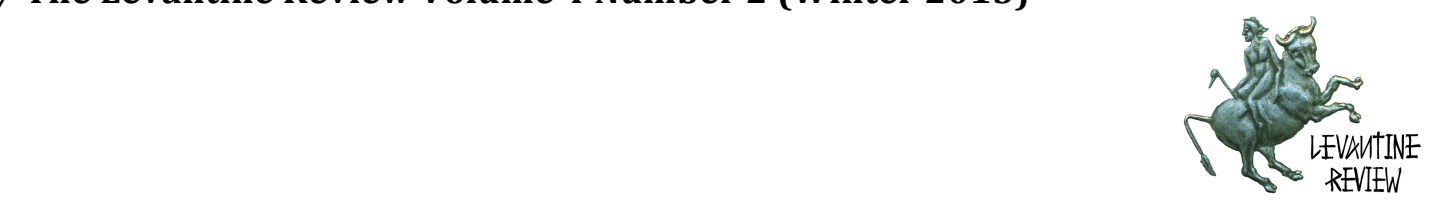

\title{
Sectarian Identities, Narratives and Political Conflict in Baghdad
}

\author{
Harith Hasan al-Qarawee*
}

\begin{abstract}
This article addresses some of the effects of political transformations and conflicts on the identity of the Iraqi capital, Baghdad. ${ }^{1}$ It illustrates the gradual "Islamization" of space by Saddam Hussein's regime, which reflected a sectarian bias as it denied Shi'a religious identity the level of visibility given to Sunni religious identity. After the fall of the regime, there was an upsurge in Shi'a symbolism and rituals in Baghdad, which further de-secularized and sectarianized the public space. The article also addresses some of the cultural consequences for the sectarian segregation in Baghdad, especially by looking into the mosques and worship places, their sectarian distribution and the contesting claims regarding some of them. The rise of sub-national cultures and the competition between Shi'as and Sunnis have further fragmented Baghdad's identity and downgraded the cross-sectarian representations. This has been mirrored in the conflict of narratives about the city which is discussed in the last part of this article.
\end{abstract}

Keywords: Baghdad, Identity, Sectarianism, Narratives

\section{Introduction}

During the last few decades, Iraqi society has been undergoing socio-cultural

transformations whereby religion and religious/sectarian identities became more salient. This transformation was recognized in the literature but was mostly viewed in relation to

1 The data collection for this article went through three stages; the first two stages were even before I decided on writing it. In 2003-2004, when I was a researcher at Baghdad University, I began interviewing people and recording my observations, examining how Iraqis were accommodating the political changes that followed the US occupation. The second stage was in 2009 when I did field research and conducted personal and Skype interviews concerning sectarian conflict in Iraq for my $\mathrm{PhD}$ thesis. When I decided to write this article during the summer of 2014, I conducted new Skype interviews with local residents in Baghdad. However, this article could not have been written without the help of my research assistant, Hazim Mohammed, and the valuable information and pictures given by Dr. Bassim Khressan, a Political Scientist from Baghdad University. 


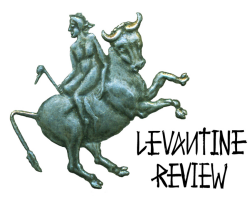

the rise of political Islam and ethno-sectarian politics. ${ }^{2}$ Less consideration was given to the study of this dynamic on the level of major cities and in relation to the socio-political context. This article is an attempt to further contextualize the mentioned transformation in a city that experienced it in relatively rapid, violent and disruptive manners.

It is often said that the question of identity has been always central in the Iraqi polity, ${ }^{3}$ due to the heterogeneity of its society, the colonial origins of its formation and, later, its post-US invasion re-modeling in a way that emphasized subnational categories. Understanding identity-related shifts and conflicts in Baghdad would shed a light on the cultural construction of political struggles and processes in post-2003 Iraq. Baghdad is not only Iraq's largest and most populated urban space (with about seven million inhabitants,) but it also had an undisputed symbolism for being the capital of the Islamic Empire under the Abbasside dynasty (762-1258.) A city with these characteristics could not be ignored in the cultural construction of the official narrative; nor was it possible to be neutralized in the struggle between sub-national groups.

When the different variations of militant Arab nationalism dominated Iraq from 1963 to 2003, Baghdad's Arab identity was emphasized more than its "Islamic" features. This was part of a frame of cultural categorization that prioritized ethnicity, rather than religion, and produced inclusion/exclusion hierarchy in which ethnic background was a valid category in the organization of political, social and cultural relations. But the secularized versions of Arab nationalism have been declining despite attempts by Ba'thists and other Arab nationalists to assert the role of Islam in making the Arab identity. Instead, there was a growing tendency to replace ethnic by religious identity as the alternative category in a new order of socio-political relations.

I argue that Baghdad's de-secularization has been shaped by two accompanying processes: Islamization and sectarianization. They were both part of a broader dynamic of identity adjustment, deeply related to the political conflicts and shifts. The increasing identification

${ }^{2}$ See for example: Khalil Osman. Sectarianism in Iraq : the making of state and nation since 1920 (New York : Routledge, 2015); Wehrey, Frederic M. Sectarian Politics in the GulfFrom the Iraq War to the Arab Uprisings (New York : Columbia University Press , 2013); Fanar Haddad. Sectarianism in Iraq: Antagonistic Visions of Unity (London : Columbia University Press, 2011);

${ }^{3}$ For further readings on that see: Eric Davis. Memories of State: Politics, History, and Collective Identity in Modern Iraq (California: University of California Press, 2005); Sami Zubaida."The Fragments Imagine the Nation: The Case of Iraq." International Journal of Middle East Studies 34, no. 2 (2002): 205-215. 


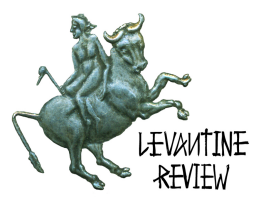

with religious and sectarian collective selfhoods resulted in the politicization of physical spaces or communal symbols and rituals that had explicit reference to these identities. In Baghdad, this led to spatial and symbolic contestations over the belonging and meaning of the city, its segments and its historical places, especially between Shi'as and Sunnis. This cultural contestation mirrored a more violent dispute that followed the US occupation and was caused by the drastic alteration of power relations from Sunni-dominated panArabism to Shi'a-dominated Islamism. This shift had a destabilizing effect on Baghdad, leading not only to high rates of sectarian violence, but also to clash of sub-national narratives about the city's identity and past. The article tries to capture both the context and the characteristics of this transitional period in which the absence of an inclusive national narrative has been exacerbated by the contestation of alternative perceptions of collective identities.

\section{Authoritarian Islamization of Baghdad's Identity}

Baghdad's special status was asserted when it became the capital of the modern state of Iraq in 1921. During the republican era (1958-present,) its political, economic and cultural status was fostered by the tendency of subsequent Iraqi governments to centralize and consolidate power. Due to centralization policies, the authorities became more interested in shaping Baghdad's spatial identity. The revolutionary nature of the republican regimes coincided with the rapid transformation of Iraq into a rentier state, highly dependent on oil revenue. This has empowered ruling elites and diminished their need to compromise with the forces of civil society and informal institutions. Their interests increasingly shifted from managing agricultural properties into organizing urban centers via manners that reflect their political and cultural hegemony.

Under the rule of the Ba'th Party (1963-2003,) especially during Saddam Hussein's leadership (1979-2003,) Baghdad was subjected to spatial and cultural reengineering processes, supervised by the president himself. The regime aimed to modernize the city in a way that reflects its security concerns and ideology. Hussein formed the Engineering Directorate as part of the structure of the Presidential Bureau, which supervised many crucial projects of construction and directly reported to him. ${ }^{4}$

Most development projects implemented by the Ba'thi government were in the center of Baghdad, on the western side (al-Kharkh,) where the regime's strongholds were located. ${ }^{5}$

\footnotetext{
${ }^{4}$ Interview with former official in the Engineering Directorate, Damascus, January 12, 2009.

${ }^{5}$ In preparation for the hosting of the summit of Non-Aligned States, a new convention center was built (now the headquarters of the Iraqi Parliament), and new high-rise buildings were constructed in the main streets leading to the center and to other governmental facilities. Families living in the old neighborhoods of Suq al-Jadid, Suq
} 


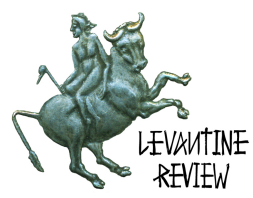

The ideological construction of Baghdad's identity during the 1980s was largely dictated by the culture of war and the personality cult. 6 The official narrative of the Iraq-Iran war manifested itself through statues and monuments celebrating Iraqi soldiers and demeaning the enemy, as was the case with three major monuments erected during the 1980s: the Monument of the Unknown Soldier (1980), the Martyr Monument (1986), and the Victory Arch (1989). Religion was not a major theme in constructing this narrative, but it was instrumental in the official discourse that sought to delegitimize the claims of the Iranian Islamist regime to being a genuine representative of Islam. The space given to religion in the official narrative was limited and strongly monitored, especially in a time when Islamist groups, such as the Da'wa Party, were conceived as enemies of the state and proxies of foreign powers.

The shift towards integrating Islam, or an amended version of it, in the cultural engineering of the city came in the 1990s, following the defeat of the Iraqi army in the Gulf War (1991) and the harsh sanctions and international isolation imposed on Iraq during that decade. The regime realized that it was no longer possible to continue governing Iraq through totalitarian methods, given that it had lost a great share of its resources. The Bath party, which had already been reduced to a security and propaganda apparatus, suffered an additional blow when thirteen provinces, inhabited by Shi'a and Kurdish majorities, revolted after the war. Although the regime retook control of the Shi'a provinces, it realized the need for other tools of control and hegemony. Secular and nationalist ideologies were waning in the whole region, religiosity was growing, and Islamist discourse was restoring its dominant position in the social culture.

Islamic characteristics made their way into the official discourse during the confrontation with the US-led coalition in 1991, when Saddam Hussein tried to use religion to mobilize

Hamada, Shaikh Sandal, Sit Naffisa and Khudhr al-Yas, who mostly belonged to the Sunni lower class, were compensated for the destruction of their houses. A considerable number of the new apartments in what has become Haifa Street and the $28^{\text {th }}$ April residential area were distributed to university professors, senior state employees and Ba'ath Party members. While this renovation distorted the historical identity of the old Baghdad, Saddam Hussein's aim was to show his foreign guests a fancy modern face of the capital. Remnants of the old neighborhoods were hidden behind the tall buildings, becoming part of the invisible Baghdad the regime wanted to conceal. Maath al-Alusi, who participated in designing the project and later became its architectural supervisor, wrote more about its management and the tension between him and the authorities. See: Maath al-Alusi, Nostos: Hikayat Shari fi Baghdad (Qobros: Manshurat al-Rimal, 2012). ${ }^{6}$ Kanan Makiya. The Monument: Art, Vulgarity and Responsibility in Iraq (Berkeley: University of California Press, 1991); Ofra Bengio. Saddam's Word : Political Discourse in Iraq (New York : Oxford University Press, 1998). 


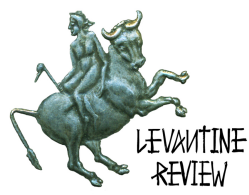

support in the Arab and Muslim world. He started to sign his speeches with a new agnomen, "Abdullah al-Mu'min" (the Faithful Slave of God.) He added the phrase "God is Great," written in his own calligraphy, to the Iraqi flag. A few years later, he initiated the "faith campaign" which reshaped the public sphere and official rhetoric. ${ }^{7}$ The campaign soon affected the cultural makeup of Baghdad when the government began to build new mosques. Saddam Hussein personally supervised the designing of four large mosques. ${ }^{8}$ The first was the Great Mosque of Saddam, which was intended to be one of the largest mosques in the Middle East. Its foundations and structures were actually built on a lot at alMuthana airport, but construction was interrupted when the war started in 2003. The second was the Arrahman Mosque, which was built in al-Mansour on a field formerly used for horse racing, which was widely seen as un-Islamic practice. This was another indication of the regime's sponsored Islamization of the public space. Another big mosque was built on the Cairo Avenue and was named al-Nida'a (the Call), referring to the day when Iraq invaded Kuwait. The fourth mosque was the "Mother of all Battles" in the al-Adl neighborhood, which was used to display a copy of the Quran written in Saddam Hussein's blood. This mosque was designed to reflect Hussein's militarized vision; its minarets resembled the Scud missiles used by Iraq during the 1991 Gulf war. ${ }^{9}$

The names of these mosques and the themes that shaped their designs say a lot about the nature of this Islamization, which was mainly about adapting Islam to the regime's myths and symbols, rather than deriving a genuine meaning from the Islamic history. Islam was conscripted to serve the regime's mythology, for which secular themes were no longer functional. Therefore, the officially sponsored Islam was not embedded socially, but was rather a tool to confront rising political Islam and coopt some of its potential constituencies.

The regime-sponsored Islamization appealed more to Sunni Muslims, since all mosques that were built were Sunni. Official institutions dealing with religious affairs were dominated by Sunni Arabs, and the Sunnism of the state's mosques was taken for granted. For the same reason, it was easier to control the Mosques' activities and their messages, especially as the regime was also seeking to monitor and contain the growing effect of Salafism in some Sunni sectors. ${ }^{10}$

${ }^{7}$ For further information, see: Davis, Memories of State; Amtazia Baramia. From Militant Secularism to Islamism: The Iraqi Ba'ath Regime 1958-3003. Woodrow Wilson International Center for Scholars:

http://www.wilsoncenter.org/sites/default/files/From\%20Militant\%20Secularism\%20to $\%$ 20Islamism.pdf

${ }^{8}$ Khalid Mutlag (Iraqi writer), Skype interview with the author, November 22, 2014.

${ }^{9}$ Ewen MacAskill. "Mosque That Thinks It's a Missile Site." The Guardian, February 20, 2015.

${ }^{10}$ A former Salafi, Interview, Baghdad, February 12, 2004. 


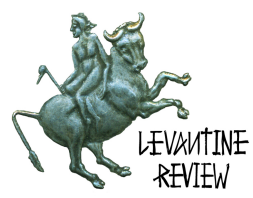

As a consequence for the increasing official care of Sunni worship places, the feeling that Shi'as and their religious symbols were being deliberately marginalized has been exacerbating. The Shi'a community, which had been becoming more conscious of its sectarian identity, felt that the state was continuing to sponsor a campaign to conceal this identity. Most Shi'a mosques or hussainiyyas (congregation halls for commemoration ceremonies) in Baghdad were built before the Ba'thi era.

However, this issue had another important aspect. According to Shi'ism, collective prayer was prohibited if it was not led by a "just imam," namely a leader or cleric who is a Shi'a and derives his legitimacy from the adherence to Shi'a doctrines. ${ }^{11}$ Fearing harassment by the authorities, pious Shi'as were not inclined to pray collectively in mosques. This position changed only when the then-rising Ayatollah Mohammed Sadiq al-Sadr reinstated the Friday prayer in al-Kuffa mosque in the city of Najaf. ${ }^{12}$

\section{Transformations of Identity in Post-Ba'th Baghdad}

The US occupation resulted in two major transformations: first, the dismantling of the power structure which had ruled Iraq for decades and had been dominated by Sunni Arabs; second, the rise of Shi'a groups and parties. As a result, there has been a radical change in the public space and its expressions. Statues and monuments representing the former regime's ideology were removed and the places that carried Saddam Hussein's name or Ba'thi symbols had their names changed. The Islamization process continued, this time through communal efforts rather than as part of an official policy. The collapse of the state and the subsequent chaos and conflicts empowered non-state actors, with no dominant official narrative dictating the cultural construction of the public space in Baghdad and other cities. Communal narratives were rising and filling this vacuum, further politicizing the fragmentation of identity.

The sense of empowerment among the previously marginalized Shi'a communities expressed itself in an increasing Shi'ization of the public space in Baghdad. Saddam City, the poor Shi'a district with more than two and a half million inhabitants, was renamed after Mohammed Sadiq al-Sadr, the Shi'a cleric assassinated by Saddam's regime in 1999 who was very popular among the disadvantaged sectors of the Shi'a community. Non-Islamist residents preferred the old name, Thawra City, which was the name chosen by former President Abdul Karim Qassim, who had ordered the construction of the district's low-cost

${ }^{11}$ Ahmed Al-Katib. Tațawur al-fikr assiyyassi asshi i: min asshura ila wilayet al-faqih (Beirut: Dar ajjadid, 1997).

12 Abbas Khadhim. The Hawza Under Siege: A Study in the Ba'th Party Archive (Boston : Boston University, 2013). 


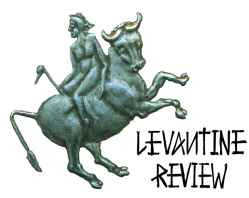

housing for the immigrants of the southern countryside who at the time were living in reed and canvas huts. ${ }^{13}$ In daily usage, the word al-Madina (the city) is widely employed in what seems to be a practical compromise between the different preferences. However, the name "Sadr City" soon became the official name, indicating which trend was the dominant in the district.

Due to the oppression and neglect this crowded city faced under the Ba'th's rule, it experienced a rapid growth of Islamist radicalism and opposition to the regime and foreign occupation. The district has been the center of the "low culture" in Baghdad. During the 1990s, it was the home of many pop singers whose artistic output was the target of criticism by classic critics for being vulgar and cheap. Some of those singers had found their way to fame through al-Shabab TV station, which was supervised by Uday Saddam Hussein. ${ }^{14}$ Many Sadrists deemed this a deliberate attempt to slight the district's youth and divert their attention from serious causes. The district was also a source of troubles for upper and middle class families in Baghdad. Over time, the cultural boundaries between the well-off segments of the population and the district's residents who were stereotypically perceived as "uneducated" and "badly mannered" were solidified.

Many Shi'as I interviewed, especially intellectuals from Sadr City, spoke about how the former regime tried to isolate their district from the rest of Baghdad in order to alienate and deprive them of the sense of belonging to the capital. The main spatial isolator was the Army Canal (Qanat al-Jaish,) a waterway connecting the Tigris and Diyala rivers and which was originally supposed to supply irrigation water to nearby agricultural areas and clean drinking water to Rusafa (the eastern side of Baghdad.) The former regime abandoned the project and, as a result, the waterway became a ribbon of stagnant water due to low water levels and lack of maintenance. On some occasions, especially when there was a big political event or security tension, said a lawyer from Sadr City, 15 "the security forces closed all entrances through which inhabitants of the district could cross the canal and we were completely isolated from the rest of Baghdad." He added that the aim was to "remind us that we were not Baghdadis, and to keep the capital's demographics consistent with the regime's sectarianism." In 2012, the Mayoralty of Baghdad commenced a large project to develop the canal and turn it into a recreational area in what seemingly was an attempt to change that history and reintegrate Sadr City into Baghdad. ${ }^{16}$ Among the residents, the collapse of the regime and its security organs created a sense of empowerment-and perhaps also a desire for revenge. The Sadri movement, led by the young cleric Moqtada al-

\footnotetext{
${ }^{13}$ Haider Attiyya Khadhim. "Al-Za'im Abd al-Karim Qassim Wa Mushkilat al-Sara'f AlMada." Al-Mada, February 23, 2015.

14 I met one of those singers who was a college student during the 1990s and managed to appear in al-Shabab TV. After the war, he joined the Sadri movement.

15 Munjid al-Mayali, Skype Interview with the author, November, 12, 2014.

16 Faris Al-Shimmari. "Mashrou Tatwir Qanat al-Jaish." Al-Ittihad, January 18, 2015.
} 


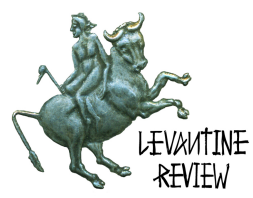

Sadr, managed to fill the void, contain this enthusiasm, and provide a sense of mission for the youth.

Pictures of Moqtada al-Sadr and his father were posted in Baghdad's Shi'a neighborhoods and even some main intersections. The Shi'a parties that returned from exile, such as the Islamic Supreme Council of Iraq (ISCI) ${ }^{17}$ and the Da'wa Party, also installed murals and billboards showing pictures of their religious and political leaders. The image of Shi'a turbans became a prominent element of an increasingly salient Shi'a identity of some neighborhoods. Simultaneously, Shi' as moved to revive their rituals publicly; among those rituals was the walking pilgrimage to Karbala to commemorate the martyrdom of Imam Hussein, the third of the "infallible imams" in the Shi'a Twelver sect. Those pilgrimages sometimes led to the closure of main roads and impeded traffic.

The increasing salience of Shi'a identity has strengthened feelings of alienation among Sunni residents in Baghdad. It was as if lay Sunni Arabs were discovering a world whose existence they had never known of. In those early years, they found themselves on the defensive side, attempting to distance themselves from the former regime and to deny that the regime had been a Sunni one. Therefore, while the mythology of the former regime was disappearing and Shi'a cultural symbols were uncovering, Sunnis began to experience identity confusion. ${ }^{18}$ They had yet to discover who they now were, as the nature of the highly centralized Iraq, which had been ruled by aggressive homogenization policies, had changed radically.

The "new Iraq" was built on the paradigm of democratic consociationalism, which recognized and institutionalized sub-national identities. Coping with the requirements of this paradigm shift was easier for the Shi'a community because it maintained its autonomous informal institutions and a highly ritualized culture that helped in reproducing the communal identity. For Sunnis, it was more challenging, since their solidarity networks were embedded in the structures of the state, which they had ruled for a long time. They had felt no need to build communal sectarian institutions outside of this structure, whose downfall left them with no solid institutions that can express this "communality."

The rate of violence in Baghdad escalated from that time, reaching the level of a civil war in 2006 when the Shi'a holy shrine of al-Askariyayyn in Samarra was attacked. In revenge, Shi'a militias assaulted Sunni mosques; street battles with Sunni insurgents and reciprocal sectarian targeting displaced thousands of families. The resultant segregation in many

17 Initially called "the Supreme Council for Islamic Revolution in Iraq" (SCIRI).

18 Talking to Sunni residents of Baghdad at the time, I noticed that many felt estranged by the increasing salience of Shi'a religious symbols and the growing influence of Shi'a clergy. 


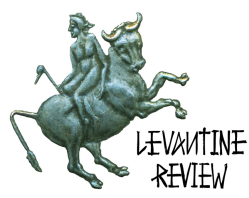

areas reduced inter-communal communication to its lowest levels. ${ }^{19}$ One outcome of the civil war and the Shi'a enablement is the assertion of Shi'a demographic and military ascendancy in the capital. Sectarian fault-lines intruded into the west, which had been a Sunni stronghold under the former regime. ${ }^{20}$ The effect of those transformations is reflected today in the changing nature of some neighborhoods and the visibility of cultural symbols that had previously been concealed.

\section{Mosques and Endowments}

The Islamization processes in a city with a mixed population and different religions and sects unavoidably granted places of worship more value. This is even truer in a context characterized by a weak state and inter-communal conflicts. In addition, the institutionalization of sectarian identities in post-2003 Iraq led to the separation between Shi'a and Sunni religious endowments. The former Ministry of Endowments and Religious Affairs was replaced by directorates representing each of the major religious groups in Iraq. For example, most religious endowments in Baghdad were divided among four directorates: Shi'a, Sunni, Christian and Sabi'i. Here I will focus on how the Shi'a and Sunni endowments and religious places in Baghdad have been administered and distributed in relation to the cultural construction of identities in the city.

As mentioned earlier, all mosques built by the former regime were Sunni mosques and administratively controlled by the Ministry of Endowments and Religious Affairs. Shi'a shrines were also within the jurisdiction of this ministry, but Shi'a rituals were autonomous practices to the extent that the regime perceived them as a potential threat and

${ }^{19}$ See for more details: Emi C. Carpenter. Community Resilience to Sectarian Violence in Baghdad (New York : Springer, 2014); Mona Damluji. "Securing Democracy in Iraq": Sectarian Politics and Segregation in Baghdad, 2003-2007." Traditional Dwellings and Settlements Review 21, no. 2 (2010): 71-87; Nils B. Weidmann and Idean Salehyan.

"Violence and Ethnic Segregation: A Computational Model Applied to Baghdad." International Studies Quarterly 57, no. 1 (2013): 52-64.

20 After the rate of sectarian violence started to drop in 2003, Baghdad's demographic makeup has been rather modified. The eastern side (Russafa) became predominantly Shi'a, and a precarious balance ensued in the western side (al-Kharkh), where some neighborhoods became exclusively Sunni and the Shi'a presence in others has been expanding. Many Sunni families migrated from al-Kharkh's northern neighborhoods that were adjacent to the Shi'a district of al-Kadhimiyya, such as al-Huriyya, al-Adl, al-Washash and al-Amil. Shi'a families were forced to leave neighborhoods with a Sunni majority such as al-Amiriyya and al-Jihad. It is possible, therefore, to say that today the sectarian faultlines are leaning towards Sunni majority areas, reflecting a military and demographic Shi'a supremacy: local residents, Series of Interviews, 2009, 2014. 


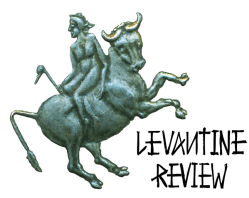

restricted-and strictly monitored-them. ${ }^{21}$ As a result, many Shi'as believed that the number of their mosques and hussainyyas was not proportional with their demographic magnitude. Some argued that the regime had deliberately increased the number of Sunni religious places to express a sectarian inclination that was deepened after the Shi'a uprising in 1991.22

After 2003, Shi'a religious institutions and parties sought to restore the community's freedom in the practice of its rituals and ceremonies. The largest and most important locus in Baghdad was the shrine of Imam Musa al-Khadhim, the seventh imam for the Shi'a Twelvers, located in the district of al-Khadhimiyya. The shrine had previously been administered by the Ministry of Endowments and Religious Affairs, which appointed its director after consulting with the Ba'th Party, often selecting a Shi'a who was affiliated with the party. ${ }^{23}$ When the regime fell, a new administration was appointed by the newlyformed Directorate of Shi'a Endowments (DSHE,) in consultation with the clerical establishment led by the grand Marja, Ali al-Sistani. The administration enjoyed greater autonomy and initiated renovation plans in the shrine, such as the replacement of the golden outer layer of its dome. ${ }^{24}$ In addition, the administration opened the Hawza of Assharif al-Murtadha as a center for Shi'a religious studies. ${ }^{25}$ Furthermore, an important mosque, Bratha, one of the oldest Shi'a teaching centers in Baghdad, which is thought to have initially been a Christian monastery, revived its Friday prayer, under the supervision of a prominent member in ISCI, Shaikh Jalal Addin Assaghir. ${ }^{26}$

In most cases, the process of deciding the authority responsible for endowments went smoothly, because religious places often reveal their sectarian identities; in addition, their

21 Official in the Directorate of Shi'a Endowments, Interview, Baghdad, January 4, 2009. 22 Widely cited to justify this argument on the regime's explicit sectarianism is a series of articles published in the official newspaper of Ba'ath Party following 1991 uprising and believed to have been approved by Saddam Hussein that attacked Iraqi Shi'as and their rituals. See: Al-Thawra Newspaper. "Madha Hașal fi Awakhir 'am 1990 wa Hadhihi alAshhur min ‘am 1991 wa Limadha Hașal alladhi Hașal.”( London: Manshurat al-Malaf alIraqi, 1991).

23 Officials in the Directorate of Shi'a Endowments, Interview.

${ }^{24}$ Shabakat al-Kafil al-Alamiyya, Iftitah Qabat al-Imam al-Khadhim Wast Ajwa' Imaniyya Amira, September 22, 2010, http://alkafeel.net/ar-news/index.php?id=263 (accessed December 8, 2014).

25 Shaikh Ahmed al-Baldawi (the supervisor on haezat al-Murtadha), Hawzat al-Murtadha fi al-Khadhimiyya al-Muqadassa inmuthej lil-islam al-hadhari, AL-Salam Organization for Feleah Kurds, April 3, 2012, http://www.failea.com/body.asp?field=news_arabic\&id=1795\&page_namper=taha (accessed February 3, 2015). 26 Shaikh Jalal Addin Assaghir, interview, Baghdad, October 11, 2003. 


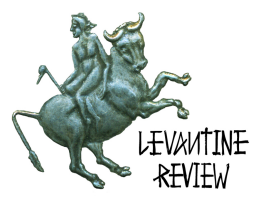

histories were intertwined with a given communal narrative. However, in the cases of recently built mosques or old mosques with controversial histories, there were disputes between the DSHE and the Directorate of Sunni Endowments (DSUE).

The inheritance of the so-called "presidential mosques," which were the mosques built by the state, was one reason for disagreement. This was the case with Arrahman Mosque, which the former regime had not completed at the time of its downfall. The mosque was possessed by al-Fadhila, a Shi'a Islamist party, which follows the teachings of Shaikh Mohammed al-Yaqubi. In another case, the association of Muslim scholars, a Sunni group, too possession of the mosque of "The Mother of All Battles" and changed its name to Um AlQura ("The Mother of All Villages,") which is one of the names of Makkah (Mecca.) As the group refused to recognize the institutions formed under US occupation, its control of the mosque was disputed by one of these institutions, DSUE, which managed to take it over in 2007. Some Shi'a officials disputed the Sunni ownership of presidential mosques and demanded their distribution equally between the two directorates. However, given that most of these mosques had Sunni imams appointed by the government, DSHE decided to accept the assignment of their ownership to DSUE, with the exception of Arrahman Mosque, which is still the headquarters of al-Fadhila in Baghdad.27

The number of Shi'a hussainyas has increased in the last decade, usually via initiatives of individuals or local communities, as Shi'as felt finally free to practice their rituals. For example, in the Palestine Street, which under the former regime had eight mosques, all of which were Sunni, there was one church and no Shi'a sanctuary, five hussayniyas were built after 2003 to host Shi'a ceremonies. According to some local residents ${ }^{28}$ the motive behind building the hussayniyas was not necessarily religious; many hoped to profit from donations of private citizens or from DSHE and from renting out their halls as funeral homes.

The (2006-2007) civil war, which was triggered by an attack at Samaraa's Shrine of the $10^{\text {th }}$ and $11^{\text {th }}$ imams for the Shi'a Twelvers, included numerous assaults on mosques in Baghdad. Shi'a militias retaliated by attacking or seizing many Sunni mosques in the city. Although the exact number of afflicted mosques is unknown, some Sunni sources estimated that 180 mosques were attacked. ${ }^{29}$ This number might be exaggerated, but the fact that the civil war resulted in a Shi'a ascendancy in Baghdad is difficult to dispute.

${ }^{27}$ Hossam Khaiallah. Lijnat al-Fak wal 'zl wa Hurub al-Awqaf. Iraq al-Qanun, March 28, 2014, http://www.qanon302.net/articles/2014/03/28/15350 (accesed November 29, 2014).

${ }^{28}$ Local residents in Palestine street, Interviews by research assistant,November 12-13, 2014.

${ }^{29}$ Shabakat Hirak, Kay la Nansa Jaram al-Militiat Ashiyya fi A`qab Tafjir Marqadei alImamein al-Askiryayyn, link is no longer available (accessed September 3, 2014). 


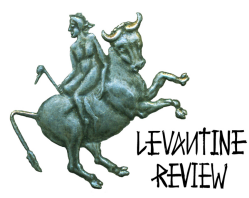

There were sites whose ownership was disputed between the Shi'a and Sunni Directorates of endowments. Among such sites was the al-Assifiyya Mosque in al-Nahr Street, which was built in 1017 and renewed in the $19^{\text {th }}$ century by the Ottoman Wali, Dawood Basha. ${ }^{30}$ Inside the mosque, there is a grave that DSHE claimed to be that of Mohammed Bin Yaqub AlKullini, one of the most distinguished Shi'a scholars (864-941). ${ }^{31}$ Sunni sources claimed that the mosque, which had for a long time been associated with the Sufi order of alMawlawiyya, actually contains the grave of al-Harith al-Muhassabi, a Sufi scholar; others said that it was of the Abbasside Khalifa, al-Mustanssir Billah. The two sides both claimed rights to the mosque until their dispute was resolved in favor of DSHE, which now manages it. Some Sunnis still claim that it was forcefully taken by DSHE, aided by the Shi'adominated government. ${ }^{32}$

As part of the endeavor to reveal Baghdad's "Shi'a memory," some neglected Shi'a symbols have been resuscitated. For example, DSHE announced on March 2014 that a grave belonging to the grandson of imam Musa al-Khadhim had been found in al-Khafafin Street Mosque, which is run by DSUE, near the historical al-Mustanssiriyya school. The announcement mentioned that the grave had been abandoned and identified as a "public toilet," 33 in what seemed to be deliberate disdain on the part of the mosque's Sunni administration. A video posted on YouTube showed men surrounding the grave and intoning a Shi'a chant, some of them weeping. ${ }^{34}$ This event was staged as another proof of the victimization Shi' as had suffered, and the role of Sunni governments in concealing their memories.

In fact, this reflects an old and, at the same time, reawakened conflict in inter-sectarian relations. Whereas the common Sunni narrative in Iraq used to glorify the Abbasside legacy and view it as the central element of Baghdad's identity, Shi'a narrative tended to be hostile to this legacy. Abbasside rulers had imprisoned and executed many of the Shi'a imams and their family members, whom they conceived as real or potential challengers to their power. The examples of the al-Assifiyya Mosque and the grave of al-Khadhim's grandson, both of

30 Jawad Mustafa and Ahmed Susa. Dalīl khārițat Baghdād al-mufașșal fí khițaț Baghdād qadìman wa-hadìthan (Baghdad : al-Majma' al-'Ilmī al-Irāqī, 1958 ); Ibrahim Al-Durubi. AlBaghdadiyuun: Akhbarehum wa majalissuhum (Baghdad: al-Rabitta, 1958).

31 Official in the Directorate of Shi'a Endowments, Interview with research assistant, July 22, 2014.

32 Ammar Mahmud, "al-Assifiyya wa akhawateha: qissat al-istila' 'la masajid ahl al-sunna." Majalat al-Ra'd, September 7, 2012,

${ }^{33}$ Al-masslah. Bilsewar: al-kashf' $n$ qabr ya'ud li hafid al-imam musa al-khadhim. March 3, 2014, http://almasalah.com/ar/NewsDetails.aspx?NewsID=27270 (accessed Spetmber 2, 2014).

${ }^{34}$ See: https://www.youtube.com/watch?v=bvbKF_aykgE 


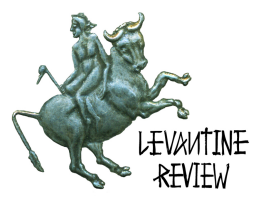

which are located in the same area of the old Baghdad, represented this clash of narratives in a time when there is a sense of empowerment among Shi'as. They are rediscovering their obscured memories in association with their political revival, which gives the sense that this "memory" was itself awakened, sometimes as a reminder of their real or imaginary "victimhood."

Another related issue was that of the "graves" of the four "deputies" of the last Shi'a imam, al-Mahdi, who were the only people allowed to contact him personally before his "major occultation," according to the common Shi'a narrative. ${ }^{35}$ The graves were known of before 2003 , but only after the regime change was it possible to make them more visible, renovate their temples and identify them with their "histories" as told by the Shi'a narrative. ${ }^{36}$ The fact that all of the last imam's deputies were buried in Baghdad served the interests of Shi'a historiography, which sought to assert the established Shi'a existence in the city and challenge the Sunni narrative that deemed Baghdad a Sunni city.

However, these efforts overlooked the fact that the former regime actually had barely privileged historical Sunni shrines, whether those of distinguished Sunni scholars such as Abu Hanifa and Ibn Hanbal, or those of well-known Sufis such as al-Hallaj, Omar alSahrurdi and Juneid al-Baghdadi. Saddam Hussein's latter-day religiosity was an attempt to build his own "religious memory," one that was associated to the regime's ideology or to his personality. It was part of what can be called the "Saddamization of religion." The kind of "Islam" it sought to "revive" was a largely ahistorical, one which obscured Sunni figures that didn't identify with the regime's narrative of the strong and unifying leader whose existence was necessitated by history. ${ }^{37}$ This can be seen, for example, in the neglected and miserable condition of the grave of the last Abbasside Khalifa, al-Musta'assim Billah, who was killed by the Mongols when they invaded Baghdad in $1258 .{ }^{38}$ The grave is located nearby the shrine of the Sufi scholar, Omar al-Sahrurdi, in the industrial area of Shaikh Omar. Al-Musta'assim was considered a weak Khalifa who surrendered to the Mongols, unlike another Abbaside Khalifa, al-Mu'tassim, whose name appeared regularly in the regime's propaganda, usually associated with Saddam Hussein, in a context where the two represented true leaders who defied and "defeated" foreign invaders.

35 The major occultation in Shi'a Islam refers to the belief that the twelfth imam, Muhammed al-Mahdi, has not died and is in hiding. Shi'as believe that he will re-appear during the "end times."

${ }^{36}$ Bassim Ali Khressan (professor at Baghdad University), Skype interviews with the author, September 3, 2014-March 8, 2016.

37 One of the many titles the propaganda machine chose for Saddam Hussein was "the leader of necessity."

38 Bassim Ali Khressan, Interview. 


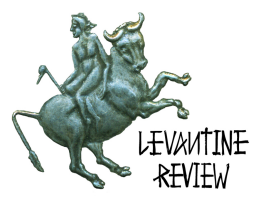

Another issue that needs to be considered here is the role of shrines in shaping the identity and historical memory of Shi'a and Sunni communities. For Shi'as, shrines are "central" because most of the community's rituals actually revolve around them. These shrines hold a level of sacredness unknown in the relationship of Sunni Muslims with theirs. Shi'a imams and their close relatives are perceived by their communities as "sacred" and "infallible," representing a divine choice; hence, they are approached as "mediators" with and "paths" to the divinity. Sunni Islam does not bestow such status to the people or their shrines. In the most literalist version of Sunnism, Salafism, praying or worshipping at the shrines is considered bida'a (innovation that deviates from the "true Islam" and leads to heresy). When the radical organization, the Islamic State in Iraq and Syria (ISIS), controlled Mosul and other Iraqi cities in June 2014, it destroyed not only worship places belonging to non-Sunni faiths, but also shrines of prophets and saints who are sacred to Sunni Muslims themselves, such as Jonah's and Shayth's tombs. ${ }^{39}$ The group also sealed Sunni mosques that had graves of their founders or prominent Sunni figures. ${ }^{40}$ Ahmed Ibn Hanbal, a prominent scholar whose teachings were highly regarded in Salafism, which represented ISIS's religious doctrine, was buried in Baghdad near al-Midan Square. The grave today lacks any institutional care. The person who is in charge of it has a paper from DSUE licensing his attendance at the grave, but he is actually not paid for this job, which he says he is doing out of respect for the scholar. ${ }^{41}$

While the Salafi disregard for the grave of one of their main religious scholars is understandable-for they disconnect the value of the grave from the history of person buried in it-the indifference of the DSUE can be attributed to political and ideological reasons. DSUE was led by a moderate figure, Ahmed al-Samara'ai, who belonged to a Sufi family, and whose dealings with the Iraqi Shi'a-dominated government were criticized by Islamist-Jihadi groups, or by factions opposing the US occupation and the political process. DSUE seemed to have positioned itself as a moderate body, adhering to Hanafism, which is believed to be the doctrine of the majority of Iraqi Sunnis, especially Sunni residents of Baghdad where the shrine of the founder of the Hanafi School is located. This perhaps explains why the grave of Ibh Hanbal lacked the same level of solemnization enjoyed by the shrine of Abu Hanifa. In fact, the latter has become the central site for Sunni religious celebrations, the most important of which being the ceremony of the birth of Prophet

39 Dana Ford and Mohammed Tawfeeq. "Extremists destroy Jonah's tomb, officials say." CNN. July 25, 2014; , Abdelhak Mamoun. "ISIL dug up grave of Prophet Younis (biblical Jonah) in Mosul." Iraqi News. July 4, 2014.

40 Al-Rafidayn. Tadmir jawami' tarikhiyya fi al-Mosul, wa al-UNESCO tujadid mawakifiha min tikrar tajawuzat daish, December 16, 2014, http://alrafidayn.net/index.php/responsive/4047-2014-12-16-22-15-09 (accessed February 12, 2015). 41The guardian of Bin Hanbal Shrine, Interview conducted by research assistant, December $13,2014$. 


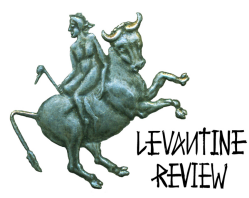

Mohammed (mawlid). The last few years have seen increasing numbers of people attending the gatherings in the shrine to celebrate the mawlid. Households in A'dhamiyya, the Sunni district that harbors the shrine, have been raising green and white flags for the occasion. This can also be interpreted as a Sunni attempt to create a communal ritual in the face of the rising ritualism among Shi'as. Haddad argued that although the mawlid is not a product of post-2003 environment, "the sudden sociopolitical relevance that Sunni Arab identity found itself burdened with in 2003, and the accompanying feelings of encirclement, undoubtedly created a need for such grand carnival-like occasions." 42

Sectarian polarization has weakened the converging memories, represented for example by the Sufi legacies. ${ }^{43}$ Those memories are still neglected as the rise of the Shi'a-Sunni divide has been consolidating exclusionary communal identities. The city also once had an interreligious memory, one representation of which is the Shrine of Shaikh Isaak in a neighborhood called al-Torah. The shrine belonged to a Jewish Rabbi, Isaak Hanun, who at one time was venerated by both Muslim and Jewish communities residing in the area. The shrine is nearly forgotten today, and according to an Iraqi journalist that visited it in 2011, its condition is much deteriorated. ${ }^{44}$ It does not seem that the authorities are concerned about reviving these converging memories, perhaps because of the Sunni-Shi'a dichotomy that governs the distribution of worship and religious places, leaving little or no space for sites that manipulate this dichotomy. Although communities use the religious sites as symbols to reproduce their collective identities, those sites alone lose their symbolism if they are not frequented by any group of people. Memories cannot stand for long when the people who practice the act and ritual of remembering them are absent.

\section{The Conflict of Narratives}

As mentioned earlier, the politicization of sectarian identities intensified the clash between Shi'a and Sunni narratives about Baghdad. Although the mainstream discourse adopted by the ruling elites and their parties tended to avoid explicit sectarian language, this language is not odd in informal platforms, especially in religious institutions or media. The Shi'a narrative seeks to normalize the Shi'a demographic ascendancy in Baghdad by "rediscovering" and "emphasizing" its memories and symbols. It seeks to uncover the way

42 Fanar Haddad. " Sectarian Relations and Sunni Identity in Post-Civil War Iraq." In Sectarian politics in the Persian Gulf, ed.Lawrence G. Potter. (New York : Oxford University Press, 2014), p.110.

43 Many Sufi figures are buried in Baghdad, such as al-Hallaj, Juneid al-Baghdadi, Ma'ruf alKhakhi, Omar al-Sahrurdi, al-Sir al-Saqti, Thanoon al-Misri and Bahlool al-Kuffi.

${ }^{44}$ Abd Arrahman al-Majidi. "Mahalat al-Torah fi qalb Baghdad... irth al-yahud al-majhub." Elaph, January 31, 2011, http://elaph.com/Web/Politics/2011/1/627356.htm (accessed September 15, 2014). The research assistant visited the place and confirmed the infomation given by al-Majidi. 


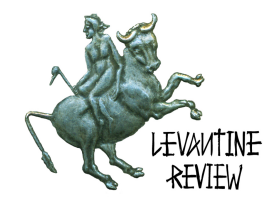

Sunni-dominated regimes reengineered the city's identity and its demographics in order to conceal or even "eradicate" its Shi'a memory and amplify its Sunni memory.

One example of attempts to rediscover the Baghdad's "concealed Shi'ism" is a "study" entitled "The Rootedness of the Shi'as in Baghdad," written by Shaikh Ali al-Korani alAmili, ${ }^{45}$ a Shi'a Lebanese cleric who previously lived in Iraq. The study highlighted that alKharkh was inhabited by a Shi'a majority when it was a village before the Abbasside Khalifa, al-Mansur, decided to make it his capital. Al-Amili focuses on the "injustices" and "oppression" Shi'as of Baghdad have endured throughout history; the roles of prominent Shi'a families in this history; Shi'a rituals and processions in Baghdad; and the history of Shi'a imams and al-Mahdi's deputies who lived in the city.

Another article, written by the Shi'a writer Taqi Jassim Sadiq, ${ }^{46}$ focused on the recent history of Baghdad and on the fact that the capital contains the largest concentration of Shi'as in Iraq and one of the largest in the Middle East. He attributed the constant attacks using car bombs against Shi'a neighborhoods to a Sunni plan to control Baghdad. He saw this "plan" as a continuity of the Ba'th policy to conceal the Shi'a features of Baghdad and to shape its demographics in a way that turns Shi'as into a minority. Sadiq referred to a decision taken by Saddam Hussein's regime that prevented those who were not registered as natives of Baghdad in the 1957 census from owning property in the city. Many Shi'as agree that there were sectarian motives behind the decision, given that the regime exempted its loyalists from this obligation. The regulations allowed inhabitants of Tikrit, the hometown of Saddam Hussein and many of his aides, to own real estate in the capital. Tikrit was administratively part of Baghdad until 1976 when the Ba'th government decided to make it the capital of the then newly-formed governorate of Salahaddin. According to a common Shi'a account, these regulations actually deepened the sectarian divide inside Baghdad by separating the population into two segments: a predominantly Sunni segment inhabiting the prosperous neighborhoods of the city (e.g. Amiriya, Khadraa, Jami'ia, Yarmuk) and a predominantly Shi'a segment living in the poor neighborhoods such as Saddam (Sadr) City and Shu'la. One of the first decisions taken by the Iraqi interim government led by Ayad Alawi (2004-2005) was to annul these regulations. ${ }^{47}$

\footnotetext{
${ }^{45}$ Ali al-Korani al-Amili. Araqat asshi'a fi Baghdad, http://www.alameli.net/books/?id=3379 (Accessed February 25, 2015)

46 Taqi Jassim Sadiq. Baghdad akbar madina Shi'yya bil'raq, http://gilgamish.org/printarticle.php?id=20410 (accessed February 25, 2015). ${ }^{47}$ Asharaqalawsat. Alyawir wa Alawi yulghiyan qanun hassr al-tamaluk fi Baghdad, August 24, 2004,http://classic.aawsat.com/details.asp?issueno=9165\&article=251774\#.VHSd2skutGY (accessed September 12, 2014).
} 


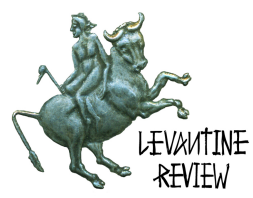

However, when looking at the demographic map of Baghdad, this narrative proves to be simplistic. Sunni majorities also inhabited lower class neighborhoods such as al-Fadhl, alKifah and al-Shawaka. None of these neighborhoods witnessed a major change in their socioeconomic conditions under the rule of the Ba'th regime. In addition, prominent Shi'a families continued to live in upper class neighborhoods, which clearly indicates that sectarian classification was not fully congruent with socioeconomic stratification. What was obvious is that the authorities used these regulations to strengthen their control over population movement in the capital. The regime's hierarchy was reflected in the spatial relations and demographic makeup of Baghdad. Connections to the regime's figures through kinship and regional affiliation were crucial in providing access to the special benefits of the upper stratum. While this stratum was not exclusively Sunni, Shi'as were obviously underrepresented because of their lack of access to the regime-sponsored patronage in the city.

The Sunni narrative sought to manifest that, following 2003, there have been sectarian policies adopted by the Iraqi government and implemented by Shi'a militias to make Baghdad more Shi'a and force its Sunni population out of the city. This narrative emphasized Baghdad's "Sunnism," which has been "eradicated" today through deBa'thification and sectarian violence. When protest movements against policies of Maliki's government started in Iraqi Sunni cities near the end of 2012 and lasted for one year, some protesters used the slogan "Marching on Baghdad" and insisted that the capital was one of the "protesting sixth provinces," implying that Sunni Arabs view the city as their own. ${ }^{48}$ Following its invasion of Mosul, ISIS also threatened to march on Baghdad and topple its "Shi'a government." This time, the threats seemed serious enough that Shi'a militias started to regroup and operate in some of Baghdad's neighborhoods.

We find different aspects of the Sunni narrative in a lecture given by Shaikh Taha alDuleimi, ${ }^{49}$ a Sunni cleric known for his anti- Shi'a rhetoric. In the lecture, he compared the fall of Baghdad to the American forces with the Mongolian occupation of the city in 1258. He described a "betrayal" by the "Shi'a" minister of the Abbasside Khalifa, Ibn al-Alqami, and an influential Shi'a scholar, Nassir Addin al-Toussi, who collaborated with Hulagu Khan (the Mongolian leader who invaded Baghdad). The two were considered perpetrators in the murder of the Abbasside Khalifa. Al-Duleimi likened this story with the behavior of Shi'a parties in Iraq, whom he accused of being collaborators with the occupation. This narrative connected the Shi'a "disloyalty" with the "Persian" historical "greed" manifesting

\footnotetext{
${ }^{48} \mathrm{Ma}^{c} a d$ Fayadh. "Qadet al-muḍaharat fi al-muhafẓat al-gharbiyya wa asshimaliyya yu'kidun al-zahf 'la Baghdad al-jum'a al-muqbil." Assharqalawsat, February 10, 2013, http://archive.aawsat.com/details.asp?section=4\&issueno=12493\&article=716619\#.VVtCz unbI5s (accessed October 10, 2014).

49 The lecture is available on You Tube and dated January 14, 2004 : https://www.youtube.com/watch?v=qnqlCY41c_4
} 


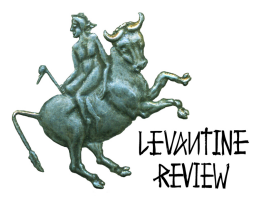

itself in today's Iranian attempts to weaken the "Arab world" and control Iraq, which was functioning as the eastern flank of the Arab world. In these narratives, the sectarian and ethnic perceptions meet to create the "other"; therefore, the term "Safavide" was often used by Sunni sectarian platforms as a derogatory term referring to the Shi'as. The term serves the purpose of identifying the ethnic side of the "other," as the Safavide Empire was Iranian, with the sectarian side, because the Safavides were Shi'a and converted Iran into a Shi'a state. Al-Duleimi said in his lecture that "there is a historically rooted conspiracy [...] a rafidhiyya [a derogatory reference to the Shi'a,] Iranian and Christian conspiracy," adding that "no enemy [has ever] managed to invade our homeland without the help of Shi'as."

A series of articles written by Abd al-Hadi Ali, 50 in an electronic journal called "Alrased," repeated some of these views. The two first articles were titled "The Iranian plan to divide the Iraqi Sunni governorates," and the third was titled "The possession of Sunni mosques is an episode in the Shi'a series of demographic changes in Iraq." It is unknown whether or not the writer used his real name, since he was identified only as an "Iraqi writer" and no other publication with his name has been found. Ali argued that since the fall of the former regime, Shi'a parties, backed by Iran, have implemented a systematic campaign to change Baghdad's demographics. He reminded his readers that "Iraq's history is full of Iranian attempts to stamp out its Sunni population." He argued that Baghdad was a Sunni city and Shi' as had no historical roots in it, to the extent that the number of Jews exceeded the number of Shi'as in the early twentieth century. For him, the main objectives of Shi'a parties today are to break the Sunni belt around Baghdad and to see more Shi'as settled in those areas.

A third narrative that can be called the "civic" narrative was usually adopted by a heterogeneous group of intellectuals, liberals, seculars and technocrats. It tended to criticize the sectarianization of politics and identity in Iraq and viewed Baghdad as a largely secular and hybrid city, hence denying the sectarian narratives and their selective readings of its history. This narrative recalled a non-sectarian memory not only during the "golden ages" of the Abbasside rule, where a degree of religious and intellectual tolerance prevailed, but also throughout decades of modernity in which a prosperous middle class existed in Baghdad and the city was a key cultural center in the region.

Examples of this narrative can be found on a website called "Baghdad's Memory (Dhakirat Baghdad)" 51 created by the Iraqi National Library and Archive. The website presents a nonsectarian vision of Baghdad and its identity and focuses on its "modern" memory. It depicts Baghdad as a hybrid space where different cultures, traditions and visions converge and

50 Abd al-Hadi Ali. "Al-istila' 'la masajid al-sunna min khuțat muselsal asshi'a fi al-taghyir al-demoghrafi fi al-iraq." Al-Rased . Alrased, June 20, 2012

51 Dhakirat Baghdad, http://www.iraqnla-iq.com/baghdad\%20memory/index.htm (accessed February 25, 2015). 


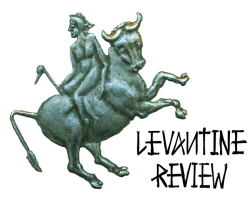

shape its unique history. Baghdad, here, is not Sunni or Shi'a, Muslim or Christian, but a city with its own particular identity that is independent of its parts. The website contains stories on the history of the city and its key districts and streets, including paintings and pictures showing the city; the traditions of its population and some of its historical moments, such as pictures of Baghdad's Queens of Beauty in the 1940s or some of its famous singers; and descriptions of the common customs of its residents.

The civic narrative is not unfavorable only to the sectarian narratives, but also of another aspect of identity and spatial distortions in Baghdad. This aspect is related to what some describe as the "ruralization of the city" resulting from the waves of disorganized migration from the countryside to the capital. The idea that Baghdad today is no more than a "big village" is recurrent in this discourse. ${ }^{52}$ This notion is embraced by the Iraqi writer and journalist Ali Abdul-Amir I'jam, who wrote several articles on the deterioration of Baghdad. He argued that the civic life and urban identity of the city started their decay with the rise of militarism after the overthrowing of the monarchy in 1958.53 In the $1990 \mathrm{~s}$, I'jam noted, "the last markers of civility vanished when remaining channels connecting Iraq to the world were cut off." He pointed out the irony that as we approach the $100^{\text {th }}$ anniversary of Baghdad's most significant street, al-Rashid, which symbolized its history and became a major cultural center, saying, "this street is occupied today by a long chain of garbage; it is abandoned because it denotes civility and also because its name is a reminder of a controversial Abbasside Khalifa, Harun al-Rashid, who is an enemy in the Shi'a sectarian narrative and profane in the Sunni Salafi narrative." Baghdad's "ruralization" can be noted in the architectural and spatial deformity that has characterized the city during the last few decades.

Some of those who adopted this view found a perfect target in the character of the former Mayor of the Capital, Na'im Ab'ub. Ab'ub is a Shi'a from Sadr City, which is mostly inhabited by families of rural origins. He managed to obtain his position through his relations with the Sadri movement and, later on, by presenting himself as a defender of the former Prime Minister, Nuri Al-Maliki, and the network of interests associated to him. The mayor's rural character, which is revealed-in the eyes of those who agree with the argument against "ruralization"-by his manner of speech, behavior and lack of modern manners, became a symbol of everything those intellectuals and liberals hated about Baghdad's current situation. They organized groups on social networks demanding his resignation or dismissal. One Facebook page, named "Baghdad in the time of Ab'ub,"54 published photos

52 I heard this description from several intellectuals I spoke to.

${ }^{53}$ Ali Abdul-Amir I'jam (Iraqi writer and journalist), Skype Interview, March 3, 2015.

${ }^{54}$ https://www.facebook.com/pages/\%D8\%A8\%D8\%BA\%D8\%AF\%D8\%A7\%D8\%AF\%D9\%81\%D9\%8A-\%D8\%B2\%D9\%85\%D9\%86-

\%D8\%B9\%D8\%A8\%D8\%B9\%D9\%88\%D8\%A8/331402893725712?fref=ts 


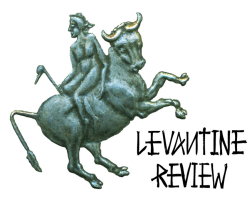

that showed the capital as a city lacking minimum public services, whose streets and neighborhoods are in very poor condition.

The rural-urban divide in Baghdad is not new and can be traced back to the 1930s when thousands of families from the southern countryside migrated to Baghdad and formed a socio-cultural group, often referred to as "Sharagwa." With the decline of the middle class and the reduction in the number of "Baghadda," that is, the families that settled in Baghdad long ago and had their own particular "Baghdadi" dialect, the social, economic and political influence of migrant families has been growing. The instability and political violence have largely dismantled the old order and caused a social mobility that benefited those who can cope with these extreme conditions. This transformation is accompanied by socio-cultural tension between the educated, urbanized strata and those with apparent rural culture. Baghdad's identity is impacted by this tension, which reflects a struggle between different understandings of aesthetic and cultural values.

\section{Conclusions}

Baghdad has been subjected to the dynamics of Islamization and sectarianization in the last twenty-five years. It might be the most extreme representation of the increasing salience of religious and sectarian identities that is ensuing most major Arab cities. The desecularization process started under the former regime, which sought to compensate for the decline of its Ba'thi ideology by coopting the rising wave of religiosity in the region. However, this Islamization was not a complete rupture from the past. The regime adapted this Islamization to its political narrative, as is reflected in the design and naming of the mosques built during the 1990s. Nonetheless, as public space and rhetoric became more Islamized, its Sunni tenets, formerly less visible behind the secular ideology, became more perceptible, especially since people were becoming more aware of their sectarian identities.

Following the downfall of Saddam Hussein's regime, the sense of empowerment among Iraqi Shi'as served to radically modify spatial relations and identity expressions in Baghdad. Shi'as attempted to ascertain their previously hidden history and communal identity in Baghdad. As this was happening concurrently with the increasing sectarian violence and political institutionalization of sectarian identities, it resulted in further sectarianization of space. Iraq had previously been ruled through the homogenization model, which coercively concealed sub-national identities and established the hegemony of a non-organic official narrative. Following 2003, the model of consociationalism prevailed, placing more emphasis on communal identities. This led to increasing segregation between communities and to disputes over meanings, memories and symbols. The Iraqi state is still weak and unable to construct a clear definition of Iraqi nationalism that can contain or conceal the cultural divide. In this respect, the continuity of conflicts, whether within political elites or between state and non-state actors, lengthens the period of instability and 


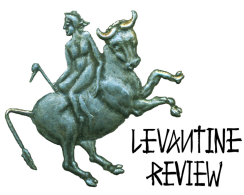

empowers communal identities. This weakens the ability to imagine an inclusive national identity that might shape the capital's identity in a less conflictual pattern.

Finally, the status of Baghdad in Iraqi federalism does not seem to have been determined. Although power in Iraq is more diffused today than it was in the past, Baghdad is still the place where most political and economic resources are concentrated. This will probably make it a locus for conflict between power and rent-seeking groups, destabilizing it further. Perhaps the capital needs to be "released" from the exaggerated concentration of power and resources in order for its rich and hybrid identity to be de-politicized. The challenge to determine how Baghdad will function in a "federal" Iraq is one that needs serious examination because it will largely decide how the whole country will function in the future.

*Harith Hasan al-Qarawee is a fellow at the Crown Center for Middle East Studies, Brandeis University. 


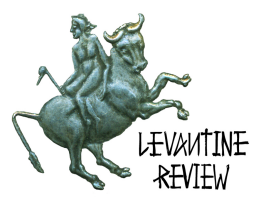

\section{Bibliography}

al-Alusi, M. (2012). Nostos: Hikayat Shari' fi Baghdad. Qobros: Manshurat al-Rimal. al-Amili, A. a.-K. (n.d.). Araqat asshi'a fi Baghdad." Accessed February 25, 2015:. Retrieved February 15, 2015, from http://www.alameli.net/books/?id=3379

Al-Durubi, I. (1985). Al-Baghdadiyuun: Akhbarehum wa majalissuhum. Baghdad: al-Rabitta. Ali, A. a.-H. (2012, June 20). Al-istila' 'la masajid al-sunna min khutwat muselsal asshi'a fi altaghyir al-demoghrafi fi al-iraq. Al-Rased . Alrased. Retrieved from http://alrased.net/main/articles.aspx?selected_article_no $=5712$ Ali, A. a.-H. (2012, March 25). Al-mukhațaț al-Irani li taqsim al-muhafazat al-sunniyya fi aliraq. Alrased. Retrieved from http://alrased.net/main/articles.aspx?selected_article_no=3392 Al-Katib, A. (1997). Tațawur al-fikr assiyyassi asshi i: min asshura ila wilayet al-faqih. Beirut: Dar ajjadid. al-Majidi, A. A. (2011, January 31). Mahalat al-Tirah fi qalb Baghdad... irth al-yahud almajhub. Elaph . Retrieved from http://www.elaph.com/Web/Politics/2011/1/627356.htm Al-masslah. (2014, March 3). Bilsewar: al-kashf 'n qabr ya'ud li hafid al-imam musa alkhadhim. Retrieved from http://almasalah.com/ar/NewsDetails.aspx?NewsID=27270 Al-Rafidayn. (2015, December 16). Tadmit jawami‘ tarighiyya fi al-Mosul, wa al-UNESCO tujadid makhawifiha min tikrar tajawuzat daish. Retrieved from http://www.alrafidayn.net/index.php/responsive/4047-2014-12-16-22-15-09 al-Rubeci, K. A. (2015, April 4). Ayahuma Akhțar: tahwid al-quds or tashye ${ }^{`}$ Baghdad. Middle East Online. Retrieved from http://middle-east-online.com/?id=128813 AL-Salam Organization for Feleah Kurds. (2012, April 3). Hawzat al-Murtadha fi alKhadhimiyya al-Muqadassa Inmudhaj Li al-Islam al-Hazari Ushriq fi Sama’ Baghdad. Retrieved from http://www.failea.com/body.asp?field=news_arabic\&id=1795 al-Shimmari, F. (2015, January 18). Mashrou Tatwir Qanat al-Jaish. Al-Ittihad . Al-Thawra Newspaper . (1991). Series of Articles: Madha Hașal fi Awakhir 'am 1990 wa Hadhihi al-Ashhur min 'am 1991 wa Limadha Hașal alladhi Hașal. Manshurat al-Malaf alIraqi .

Asharaqalawsat. (2004, August 24). Alyawir wa Alawi yulghiyan qanun hassr al-tamaluk fi Baghdad. Retrieved from http://classic.aawsat.com/details.asp?issueno=9165\&article=251774\#.VHSd2skutGY Assaghir, S. J. (2003, October 11). Bratha Mosque .

Ayubi, N. N. (1991). Political Islam : religion and politics in the Arab world. New York: Routledge.

Baghdad, S. r. (2009-2013 ). sectarianism in Baghdad. Baram, A. From Militant Secularism to Islamism: The Iraqi Ba'ath Regime 1958-3003. Washington DC: Woodrow Wilson International Center for Scholars. Baram, A. From Militant Secularism to Islamism: The Iraqi Ba'ath Regime 1958-3003. Washington DC: Woodrow Wilson International Center for Scholars. 


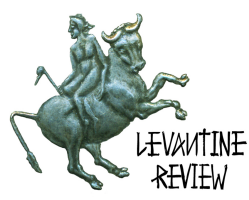

Bengio, O. (1998). Saddam's Word : Political Discourse in Iraq. New York: Oxford University Press.

Boer, L. (2006). Islamising modernity, individualising Islam? Third World Quarterly, 26 (2), 1189-1199.

Buearu, F. o. (2009, January 12).

Carpenter, A. C. (2014). Community Resilience to Sectarian Violence in Baghdad. New York : Springer.

City, S. L. (2014, November 12). Sectariianism in Baghdad.

Damluji, M. (2010). Securing Democracy in Iraq": Sectarian Politics and Segregation in Baghdad, 2003-2007. Traditional Dwellings and Settlements Review , 21 (2), 71-87. Davis, E. (2005). Memories of State: Politics, History, and Collective Identity in Modern Iraq. California: University of California Press.

Endowments), (T.G. 2014, July 22). Endowments .

Fayadh, M. (2013:, February 10). Qadet al-muḍaharat fi al-muhafzat al-gharbiyya wa asshimaliyya yu'kidun al-zahf 'la Baghdad al-jum'a al-muqbil." Accessed by.

Assharqalawsat.

Haddad, F. (2014). Sectarian Relations and Sunni Identity in Post-Civil War Iraq. In L. G. Potter (Ed.), Sectarian politics in the Persian Gulf. New York : Oxford University Press. Haddad, F. (2011). Sectarianism in Iraq: Antagonistic Visions of Unity. London : Columbia University Press. I'jam, A. A.-A. (2015, March 3). Baghdad's Identity .

Khadhim, A. (2013). The Hawza Under Siege: A Study in the Ba'th Party Archive. Boston : Boston University.

Khadhum, H. A. (2015, February 23). Al-Za'im Abd al-Karim Qassim Wa Mushkilat al-Sara'f Al-Mada. Al-Mada .

Khaiallah, H. (2014, March 28). Lijnat al-Fak wal 'zl wa Hurub al-Awqaf. Iraq al-Qanun. MacAskill, E. (2015, February 20). Mosque That Thinks It's a Missile Site. The Guardian .

Mahmud, A. (2012, September 7). 'n al-Assifiyya wa akhawateha: qissat al-istila' 'la masajid ahl al-sunna. Majalat al-Ra'd. Retrieved from

http://www.alraeed.net/raeedmag/preview.php?id=3407

Makiya, K. (1991). The Monument : Art, Vulgarity and Responsibility in Iraq. Berkeley:

University of California Press.

Mamoun, A. (2014, July 4). ISIL dug up grave of Prophet Younis (biblical Jonah) in Mosul.

Iraqi News . Retrieved from http://www.iraqinews.com/features/urgent-isil-dug-graveprophet-younis-mosul/

Mustafa, J. a. (1958). Dalīl khārițat Baghdād al-mufașșal fi khițaț Baghdād qadīman waḥadìthan. Baghdad: al-Majma' al-'Ilmī al-Irāqī.

Mutlag, W. K. (2014, November 22). On Culture and Politics under Saddam Hussein . Osman, K. (2015). Sectarianism in Iraq : the making of state and nation since 1920. New York : Routledge.

residents, l. (2009-2014). Sectarian Violence . 


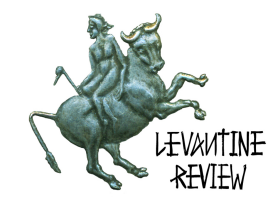

Sadiq, T. J. (n.d.). Baghdad akbar madina Shi'yya bil'raq. Retrieved February 25, 2015, from http://gilgamish.org/printarticle.php?id=20410

Shabakat al-Kafil al-Alamiyya. (2010, September 22). Iftitah Qabat al-Imam al-Khadhim Wast Ajwa' Imaniyya Amira . Retrieved from http://www.alkafeel.ir/arnews/index.php?id=263

Shabakat Hirak. (n.d.). Kay la Nansa Jaram al-Militiat Ashiyya fi A'qab Tafjir Marqadei alImamein al-Askiryayyn . Retrieved February 2, 2015, from http://www.herak.info/18269 Shrine, T. G. (2014, December 13).

Tawfeeq, D. F. (2014, July 25). Extremists destroy Jonah's tomb, officials say. CNN . Retrieved from http://www.cnn.com/2014/07/24/world/iraq-violence/

Tibi, B. (2005). Islam Between Culture and Politics (Second ed.). New York: Palgrave . Wehrey, F. M. (2013). Sectarian Politics in the Gulf - From the Iraq War to the Arab Uprisings. New York : Columbia University Press .

Weidmann, N. B. (2013). Violence and Ethnic Segregation: A Computational Model Applied to Baghdad. International Studies Quarterly , 57 (1), 52-64.

Zubaida, S. (2002). The Fragments Imagine the Nation: The Case of Iraq. (R. A. Louis, Ed.) International Journal of Middle East Studies , 34 (2), 205-215. 